\title{
Florilegium
}

\section{Volume 15}

1998

Canadian Society of Medievalists/Société canadienne des médiévistes

Department of English, The University of Western Ontario London, Canada 


\section{Postmodern Middle Ages:}

\section{Medieval Music at the Dawn of the Twenty- First Century}

\section{Annette Kreutziger-Herr}

In the October 1995 issue of Good Housekeeping, there appears an advertisement for a new "Barbie Collector's Series," featuring for the first time a doll called "Medieval Lady Barbie." Clad in a precious garment of the high Gothic style, this icon of our time is a dramatic representation of how the Middle Ages are perceived in popular culture at the end of the twentieth century. Medieval Lady Barbie is certainly not meant to function as an historically accurate document: she is first of all a toy, one of Mattel's many collector's series toys (compare Ebersole/Peabody 16, and Rand 164), and the use of a medieval garment for this twentiety-century doll illustrates that the Middle Ages have become a kind of treasure trove that can be mined in any way we like; they have become a kind of "queer accessory," as Erica Rand has expressed it in her anthropological study of the Barbie. By using a medieval dress, the maker does not wish to allude to the Middle Ages as a whole; rather, he wishes to play with isolated aspects of the distant era. The dress has a strangely comforting quality about it and an emotional nearness that is both apparent and mysterious. These qualities stem not from the Barbie, nor from the medieval accessory alone, but from the combination. The imagined dialogue between the Middle Ages and the twentieth century should convey an assurance to the modern reader that, amidst all the social, cultural, and political chaos present at the dawn of the twenty-first century, there are constants in our cultural understanding of ourselves, in our cultural identity. The reality, of course, is that there is no dialogue going on. The Middle Ages has its twentiethcentury speakers; the past can never speak for itself. The present takes over this function, for it has tamed the Middle Ages. 
As our era swallows up the earlier one, it denies it its individuality and completeness, while at the same time supposedly gaining for it some substantiality and integrity. The Middle Ages serves as a toy. It is the sum of small pieces of hidden meaning, a collection of diffuse images and yearnings illustrating that this time has indeed sunk into oblivion, but it has left behind a treasure of legends, ideals, dreams, hopes, and "visions." As the Mattel introductory text states:

Let's journey back to Medieval times of 1400, where the beautiful Lady Barbie is wearing a richly elegant ... gown with golden trim ... Medieval Lady Barbie is gracious, elegant, and timeless. Her beauty symbolizes the richness of the Middle Ages and its contribution to our exciting past (Text on the packaging for "The Great Eras Collection: Medieval Lady ${ }^{\mathrm{TM}}$ Barbie $^{c}, "$ Mattel).

The reduction of the Middle Ages to a decorative function has nothing to do with the Middle Ages and everything to do with our era: the Middle Ages have become part of the vocabulary of our time-they have become present in the twentieth century. Why is this so? And how are we to construe the sense of this word "present"? What is "present" when we speak of the presence of the Middle Ages? And is it sufficient simply to state the profound interest and, in a sense, deep yearning for the Middle Ages that many people have today?

We are in the midst of a worldwide, self-conscious and self-reflexive debate on postmodernism. The debate began with works such as Leslie Fiedler's ground-breaking article "Cross the Border, Close that Gap!" appearing in Playboy in 1969; with Charles Jencks coining the terms "double coding" and "divergent signification" (Jencks 288-9); with Jean-François Lyotard's book La condition postmoderne. Every country in the western hemisphere has now entered this debate. A few influential texts such as those mentioned above have crossed national borders and become widely known in translation; others have been influential in the creation of schools of thought only in certain parts of the world. An example of the latter is Peter Sloterdijk's Kopernikanische Mobilmachung und ptolemäische Abrïstung, which avoids the term "postmodernism" while analysing it with complete mastery. This book has proven to be one of the main sources on postmodernism for many young Dutch and German composers, while nevertheless remaining practically unknown in other parts of the world.

In general, any discussion of who and where we are serves to move us for- 
ward-wherever that may be-and ensures that in the wake of crumbling foundations communication continues:

The effort to understand our historical presence, to perceive the interactions of language, knowledge, and power in our epoch, to valorize the living categories of our existence-surely that effort deserves our wakeful respect. More concretely, the central nisus of literary history in our timenamely, to problematize periodization, to apprehend history as theory, theory as literature, and literature as both history and theory-that nisus, I think, depends on our self-conceptions, to which postmodernism is crux. (Hassan 304)

Although in recent years philosophical, musicological, and aesthetic discussions have been evolving around the term postmodernism, these have not yielded definitions upon which everyone can agree; individual positions are, in fact, often irreconcilable. Yet it seems that some observations are appearing consistently in most texts. The deconstructive aspects of postmodernism include indeterminacy; fragmentation; dismantling the canon; a loss of self and of depth; a sense of the other, the non-identical which leads to unrealistic and non-iconic art and music and inclinations towards silence in literature and music; and the sense that others are defined by negation, through a system of oppositionality which is nevertheless far from stable. The reconstructive aspects of postmodernism include irony; canevalisation; the invitation, through the indeterminacy of the work of art, to perform, to be involved in the work; construction "away from unique truth and a world fixed and found" to "a diversity of right and even conflicting versions or worlds in the making" (Goodman $\mathrm{x})$; and hybrids of mixtures of genre which lead to parody, travesty, pastiche, particularly since the copy or the image is as "authentic" as the original.

The reconstructive aspects and forces of postmodernism, particularly as evident in hybrids with their new and often wild mix of past and present, allow for a new and interesting approach to the past. Seldom is the past approached as "dead material," as an over-estheticized form (Kuspit): this is particularly true for the Middle Ages. The past is, rather, approached as a symbolic form (Cassirer, Bourdieu), as a living, symbolic essence-not in the ontological sense, though-filled with contemporary hopes and with contemporary understanding: in a word, with meaning:

In fact, hidden behind the self-importance of the parodic return of the past, there is an attempt to achieve some kind of intimate relationship to it. Post- 
modernist architecture attempts to appropriate the past not as a dead, overestheticized form but as a living, symbolic substance, charged with contemporary significance-which is the only way the past can remain viable. The return to the past is in effect a criticism of the present's lack of integrity, and is in purpose motivated by an effort to recover that integrity in symbolic form. For authentic postmodernism, the past represents lost integrity, the "home" the subject no longer inhabits but still yearns for, namely its own sanity and general good. The past is re-enacted less in the spirit of parody than of empathy, however incomplete. Pre-emptively to interpret the postmodernist appropriation of the past as parodic - a kind of witty "off" parroting of it-is to ignore the latent empathic reasons for seeking out a relationship with it. That empathy may miss the full reality of that pastand may be a form of knowing mystification to some-but this reality always exists archaeologically, through its reified information signs and ideal constructs .... Postmodernism thus represents an expanded sense of the possibilities of the past. (Kuspit 63-7)

Decades earlier, Adorno voiced a similar opinion in one of his lesser-known writings, "Ohne Leitbild." His fundamental question is the same as Kuspit's, namely, why we look so "hopefully" and yearningly to the past. His answer is:

Norms made sense originally because of what Hegel has called their substantiality ... Those norms, no question about it, reflected a certain unity of life and spirit. Without such substantiality, without the spirit being reflected in the norm, which acts according to them, it is vain to chase after norms and models. It is no concidence therefore that we now reach out for the past. We realize today that substantial norms are missing: and to declare them anyway would spring from an arbitrary act. But still we entrust the past with substantiality. And it remains unrecognized that the process, which erased the norms, is irreversible. (Adorno 297-8, my emphasis)

This yearning for the past, the desire for great works of art whose authors and originators are long dead and buried, is to a certain degree irrational. We cannot revive the past, nor would we want to, at least not in all its complexity. Medieval Lady Barbie can reflect no medieval work. The norms of musical works, as reflected in style, form, harmony, melody, and rhythm, are also time-bound and changeable. These norms are shaped by artistic, sociological, psychological and political contexts, which is what makes them historical and which also imbues them with their power. But the 
present has a deep interest in these historical norms, which have come to exist side by side with contemporary musical norms: one manifestation of postmodernism in music is the simultaneity, the Gleichzeitigkeit of past and present.

Even when we approach the past with a more empathetic than parodic slant, our understanding of it will still remain fragmentary. Empathy results in a conscious mystification of the past; this past reality exists as a secret world. The presence of the past in the present hints at the fact that what matters most is consciousness, a consciousness informed by knowledge and feelings about the past in the present (Taruskin). The postmodern approach has much to do with "entrusting the past with substantiality," with an "expanded sense of the possibilities of the past," and the postmodern approach to medieval music epitomises how the Middle Ages-here symbolising "the past" in general-are viewed. Medieval music is an appropriate site for this discussion since its rediscovery took place only a hundred years ago. Compared to other fields of knowledge, medieval music is especially young.

The rediscovery of medieval music in the twentieth century is a complex phenomenon. Five threads are woven in: a) Post-Romanticism, whose increasing social and political unrest manifested itself in music as a desire for something stable, whole and meaningful (words with which medieval music would soon be described); b) Wagner's enormous popularity among European musicians of the late nineteenth century (to the dismay of some French composers), which brought medieval subjects and traditions into focus; c) a continuing growth of musical styles which employed significant elements from national folk idioms and had the general effect of opening listeners' ears to all kinds of music; d) the movement of neo-Classicism, which incorporated new discoveries from early music into contemporary musical styles, such that new works had more or less overt connections with principles, forms, and techniques of the past; and e) a reaction against the twelve-tone approaches of Schönberg, Berg, and Webern which culminated in a return to audience-accessible, eclectic, simpler forms.

At the beginning of the twentieth century, then, medieval music satisfied the desire for something old and something new simultaneously. Antiquity left some examples of music theory, but no music, and so medieval music was the oldest European music one could possibly hear. Medieval music appealed simultaneously to the emotions and to the intellect with its artful allusions to numerical systems and theoretical concepts. It was at the same time incredibly new, like Schönberg's dodecaphonic music, or Bartok's music, which was infused with folk idioms. In our own 
time, at the dawn of the twenty-first century, the presence of medieval music, both qualititatively and quantitatively, is enormous in the current musical landscape. The popularisation of medieval music is greatly aided now by the mass media (Elste, Levin 1994), and there continues an early music movement which speaks to the amateur, or Liebhaber, as well as the connoisseur, or Kenner, and to the ever-broadening musical audience. How varied the presence of medieval music is in the 1990's can be seen in the following three examples, which are in many ways typical of the approaches being taken.

First is the question of Gregorian chant and pop. Composers and musicians throughout much of the twentieth century had little or no interest in Gregorian chant, but this changed rapidly in the 1990's. Two important trends are evident in the reception of Gregorian chant today. Both use the chant as a "mystic substance," invoking something meaningful, yet frightening, something peaceful, yet distant and transfigured. The first use does not affect the music itself (that is, it sounds much as it may have in the Middle Ages), but demonstrates how this music is reaching an increasingly large audience. Evidently this audience has been prepared enough through the use of Gregorian chant in film music (for which see Schubert, following), and through a long history of medieval imagery present in contemporary literature and art to connect Gregorian chant with these preconceived and fragmented notions. The tremendous success of Canto Greqoriano, music by the choir of the Spanish monastery at Santo Domingo de Silos (some of the pieces recorded as early as 1968; re-released in 1994), the 1994 and 1995 releases by Sequentia, Ensemble für mittelälterliche Musik Köln (Deutsche Harmonia Mundi) -an American early music group based in Germany-are interesting to consider here. Sequentia's recordings present the music of Hildegard von Bingen with catchy titles: "Canticles of Ecstasy" and "Voice of the Blood;" by contrast, their first Hildegard von Bingen recording was conservatively entitled "Symphoniae. Geistliche Gesänge" (Sacred Songs). These recordings are not crossover productions in the proper sense of the term, yet they profit from a new openness to sacred monophonic music, and they are strategically placed within a market serving all kinds of esthetic interests. They are produced using an enormous amount of reverb, or echo, designed to envelope the listener in a wash of sound and to make these recordings sound like popular music in which this production value is widely used. Although these recordings are still part of the historical performance movement, their marketing and sound ideals indicate a definitive break with the principles of this movement. Note the press release for yet another recording: 
Songs of love and pain of desire and yearning.

Songs of sensual pleasure and intimate passion.

Songs of the mighty heaven and the weakness of the flesh.

The Ancient Miracles. Ensemble fur frühe Musik, Augsburg.

The Original Sound of the Middle Ages on CD!

Since there is no "original sound" of the Middle Ages, this term is evidently meant to draw a distinction between the ideal of "authentic" historical performance and the stylistic category that one could call "Sacro-Pop" (Umbach, Salomon). In the latter, sacred music is mixed with elements of pop, a mix that takes advantage of the fact that, on a musical level, Gregorian chant is to a certain degree formless-at least to modern ears. Also, conveniently, it is not protected by copyright laws. Extreme examples of these kinds of crossover productions are the recordings by the group Enigma and Vision: The Music of Hildegard of Bingen. The latter sold over 250,000 copies within a few weeks, and ascended to the top of the pop charts. At the time of writing, it is approaching the mark of one million copies sold. Accompanying this release was a book containing elevated and esoteric notions about Hildegard von Bingen (Bobko). Hildegard von Bingen thus became, again, in the 90's a "marketed saint," even as she had been during the first Hildegard craze in the 1980's. She was also the subject of two highly-publicised conferences held in 1996 and 1997 at the Catholic Thomas-Morus Akademie in Bensberg near Cologne.

The packaging of the Vision crossover production is illuminating for our purposes here:

Evolving across a span of 800 years, Vision is a collaboration between two creative artists who never met. They lived on different continents, in different times. They spoke different languages, ate different foods, labored in different arenas, and confronted very different struggles from day to day. What binds these two, Hildegard and Richard Souther, is the light that guides them in their lives. And they meet through the continuum of music, a fluid creative place where they have made something new out of something old in Vision, a work of art that moves, energizes and soothes. (Vision, booklet, p. 6).

Richard Souther, American composer and producer, discovered Hildegard of Bingen through her sequence "O Euchari in Laeta Vita." He was especially fascinated with the opening melodic gesture, a rising interval of a fifth, followed by a fourth, 
which is characteristic of her style. His interest led him to begin the Vision project, which he and others have referred to as a "collaboration." He invited Emily van Evera, a well-known singer of early music, and Sister Germaine Fritz, O.S.B., to record Hildegard's chants as they are written, that is as solo melodies. He then combined samples from these recordings with computerised MIDI sound. Hildegard's chant has fixed pitches and free rhythms, and it functions within the boundaries of the ecclesiastical modes; but for centuries, chants have been accompanied on the organ in Catholic churches throughout the world, and as a consequence have been forced into major-minor tonality, so Souther's "arrangements," which do the same, are not unusual in this respect.

The physical collaboration between Souther and Hildegard is of course fictional, since one partner has been dead for 800 years; the substance of the collaboration is also denied, since the dead collaborator cannot prevent her creative product from being used in ways other than she originally intended. The mystic substance of Hildegard's music is exploited, and although a deep respect for her as an innovative composer is expressed in the booklet:

Hildegard blithely broke the rules of the music of her time in casting her vaulting melodies. What transforms them ... is how her poetry turns those melodies into virtual prisms. Change the text, and a repeated melody is suddenly transformed. Great modern songwriters know this well, just as they know the importance of alliteration and the delicate balance of syntax ( $\mathrm{p}$. 7).

The recording, rather than Hildegard, is what is "breaking all the rules" here. The texts, as well as the music, are altered-for example, grammatically crucial elements are deleted, some texts reproduced in the booklet are not sung, clips from sequences are inserted into antiphons and vice versa, the translations from Latin (from Hildegard's mittellatein), display no understanding of this language. But interestingly enough, none of this matters. Even Sister Germaine, interviewed on CBS television on 20 October 1995, spoke only of the wonderful experience she had making the solo recordings for the Vision CD. For her it was a religious experience, and the pop arrangements and marketing strategies were, for her, not worthy of comment.

Two examples from the recording will be briefly examined here. Both deal with Hildegard of Bingen's chant in praise of St Euchary. The title track, "Vision," appears third on the $\mathrm{CD}$, and the reprise, "Vision I," as arranged and mixed by Coolanii, is a 
bonus track included on some versions of the CD. In "Vision," Richard Souther has taken the solo version of this piece, sung by the English soprano Emily van Evera, and added samples (in this case four-bar phrases of music) recorded by Abraham Laboriel (a studio bass player), Marcus Miller (who arranged the CD Tutu by Miles Davis) and John Partitucci (who plays both electric and acoustic bass in Chick Corea's band). These patterns have been sonically manipulated by Souther using digital interfacing. Since the phrases are agogically identical, it is evident that they have been shifted and cut as well as repeated. The congas add a "world beat" influence to the piece-indeed, one could call this rendition of "Vision" the "world beat" version, and the following might be the "trance" version.

In "Vision I," the slow techno groove is shaped by an especially strong computerised sound. The harmonic pattern developed by Souther for "Vision" is followed closely (eDDDeaFee). Before and after the Chorus, which is repeated twice, e minor serves as a kind of pedal point or drone over which there occurs a synthesiser sequence. During this bridge, a filter is slowly opened, changing the overtone spectrum-an especially-loved effect of techno music. Here follows a more detailed analysis of the formal elements of the piece:

0" - 18" First bassline (E major), sixteenth notes (10" Vision sample)

$18^{\prime \prime}-35^{\prime \prime} \quad$ two-bar ostinato is added and repeated four times

$35 "-52$ " two-bar vocal phrase is repeated twice to fill four bars

52"-1'32" Chorus, heard twice, including a "spinet sound" (arpeggiated chords); the second time, a "techno" bass line is added

l'32"-1'59" two-bar vocal phrase (heard twice) after a long-held pitch (a'); bass line again in $\mathrm{E}$ major

1'59"-2'16" Synthesizer sequence; open filter to 2'16", "Visio," then bass entry

2'16"-2'53" Filter closes, "Vision" sample heard again; two filters shifted against each other

2'53"-3'32" same as $52^{\prime \prime}-1$ '32" only now with synthesizer sequence

3'32"-3'54" "Vision" sample, four bars of music, "Vision" sample plus longheld pitch, plus fade out (at the end a bell sound-F major)

Whereas in the "world beat" version the meditative character of the original is supported by the instrumental accompaniment, here the medieval chant has the effect of contrast within a collage. In fact, one could say that the chant is here a foreign element. 


\begin{abstract}
Another way of utilising medieval music in contemporary composition is to incorporate it on the structural level. There are hundreds of examples of this sort of "creative reception" in the music of twentieth-century composers: for example, Stravinsky's Mass composed between 1944 and 1948, and Hindemith's "Yale" pieces, which invoke Perotin (Traub). Composers working after World War II and contemporary composers were even more inspired by medieval music, mostly by the polyphony, and found a new musical language of their own by leaning upon Medieval models. Composers such as Lou Harrison, John Corrigliano, Wolfgang Fortner, Maurizio Kagel, Arvo Pärt, Steve Reich, Patricia Van Ness, Robert Kyr, Cary Boyce, Sid Corbett, John Adams, Sofia Gubaidulina, Alfred Schnittke, and Manfred Stahnke were and are fascinated by medieval models of rhythm, metre, melody and harmony, and it is worth studying their very individual approaches and solutions to compositional problems.
\end{abstract}

One example which again draws on Hildegard von Bingen is "Cantiones de Circulo Gyrante" by the German composer Klaus Huber. This work, which has the subtitle "A Requiem on Texts by Hildegard von Bingen and Heinrich Böll" was commissioned by the Bachverein of Cologne to celebrate the reconstruction of Romanesque churches in Cologne which had been destroyed during World War II. The work was completed in 1985 . Huber's idea was to incorporate reflections on the destruction itself, as well as the cause of the destruction, and also to record the rich culture of Cologne during the High Middle Ages. In dealing with contrasting spiritual and material worlds that are nearly one thousand years apart, Huber insisted on Gleichzeitigkeit without the reconciliation of contrasts. As Brian Ferneyhough put it:

Common to all his [Huber's] works is abundant evidence of a superiorindeed masterful-command of instrumental and textual sources, a deep, natural introversion of expression (sometimes all the more poignant and striking when deliberately projected outward in works of more public dimensions) and a control of musical time second to none. His is a humanistic art, in the double sense of fidelity to traditional concepts of craftsmanship and the unremitting demands he (justifiably) makes on music as the ultimate visionary vehicle for ideals of a high ethical endeavour (p. 11).

And, while Hildegard's texts, as chosen by Huber, deal with the "circle of time" and the "circling of time," Heinrich Böll's texts-as can be expected from one of the most famous German authors and poets of the far left-insist on decay and decline, choosing such evocative terms as "Schutt," "Asche" and "Staub." In order to avoid the 
danger of "reconciliation," Huber developed the concept of "Simultane Raumkomposition," using the Romanesque cathedral of St Maria im Kapitol, and splitting up the choirs, instrumentalists and speakers into several groups, which serve either a "Requiem" layer, presenting liturgical texts from the Mass for the Dead, the "Hildegardis" layer, the Hildegard complex, or the "Böll" level:

The music of the Hildegard complex is spatially deep-set; it arises from the depths of the church interior and cannot be precisely localized. I imagined a sound without location, which would take effect "like a vision" acoustically. By contrast, the Böll level can be precisely located in space; it presents the text in a readily understandable way and brings a realistic element into play, emphasized by its sound (Huber).

In placing the medieval elements of the composition in such a way that the sound is perceived without reference to a specific location, Klaus Huber created a metaphor for historical nearness and distance. For people living in the twentieth century, the memory of World War II is still vivid, whereas Hildegard von Bingen is, even on the material level of the literary and musical as well as the archaeological sources-only partially recognisable. In this sense her voice comes, indeed, from other times and spaces.

At one point, both Hildegard's text and her music are quoted (from the chant "O gemma splendissima") and Huber goes so far as to link his own aesthetics of composition with those of Hildegard and other medieval composers, especially with respect to the concept of "materia:"

The various materials producing noises had their place within the Materia concept of the Hildegard texts. And in addition the linking of the position of the five instrumentalists with the time network assigned to them leads to a constant, repeatedly superimposed circling of these sounds in their space: from East to North, West and South, and back to East. A Wheel of Time, in a word, with reference to the work's title and to Hildegard. The Circulus Gyrans of the Divine Light is without end. So God's power and work encircle and embrace every creature (Huber).

A final way of re-creating medieval music is to combine "authentic performance" with improvisation, serving at the same time both the desire for "pure" medieval music and the play that jazz allows (for discussions of authenticity see Taruskin 51- 
197, Kenyon). A famous European example is the recording Officium, in which the Hilliard Ensemble joined forces with saxophonist Jan Gabarek to perform pre-seventeenth century music (Levin 1995). Using medieval music as a point of departure for improvisation, the historical dimensions of the medieval models here are less important than the final "product," giving us an example of postmodern indeterminacy. In a concert that took place in July 1995 at Hamburg's main church, St Michael's, the Hilliard Ensemble and Jan Gabarek performed most of the pieces from the Officium $\mathrm{CD}$; it is especially appropriate that the concert should have taken place in a church, since the title of the CD already hints at the liturgical character of the musical enterprise (it should be noted, for example, that not all the "early" music used on the CD is sacred, so the title does not stem from that). The concert itself was announced with a poster that replicated the CD cover, alluding to a linkage between the public performance and the issuing of the associated publication new in the realm of classical music. The concert hall was filled mostly with young people, whose sense of anticipation was as charged as if some popular music idol were about to appear. This air of expectancy was very different from the feel of a traditional early music concert. It was not a scholarly expectancy, the expectancy to learn something-as was prevalent during concerts given by the Hilliard Ensemble in the early 1980's-but the expectancy to experience something. No one noticed that the pieces were not performed in the order of their appearance on the program. This simply didn't matter. What mattered was sound. The performers themselves, wearing black trousers and brightly coloured shirts, were scattered throughout the church. One by one they stood up and walked and sang their way across the church, down from the balcony, towards the altar, with their heads bent like monks who were absorbed in some kind of personal meditation.

The concert, like the recording, was somewhere between the secular and the sacred. It was a kind of religious experience, but one that permitted either participation or uninvolved observation. As Katherine Bergeron has written of a similar ocasion:

This was a concert that treated the church as a meaningful, functional space, rather than ignoring its meaning. This concert presented a virtual liturgy .... It is the condition of being between two realities, both of which are offered and both of which are denied, that creates the desired effect of this music.

Bergeron further argues that her concert, like the one I am describing, strained the 
limits of "authenticity" at the same time as it opened a new arena in which the "authentic" might be reimagined: in the virtual space of a neither/nor (Bergeron 1995 and 1995a). In thinking about my concert, I wondered how the "in-between" could be so attractive, since both the musical reality, which could provide a maximum of depth, and the religious reality, which could provide a maximum of realisation and enlightenment, were denied. John Potter, the Hilliard Ensemble's tenor, alludes to this mixture of musical and religious experience, perhaps unwittingly, when he describes the recording experience of being "shut away in the monastery of St Gerold," where "the saxophone became an extension of our own voices" (Officium).

More, however, than "the eternal touch," its intrinsic beauty, or its archaic quality makes many composers, musicians and listeners in the twentieth century fascinated by medieval music. They are not only looking for a musical model that existed before the bar line was invented, before major-minor tonality came into play, or before four-four time existed: as intriguing as these elements may be, they are also looking for something more in this "vorbürgerliches Zeitalter," as Adorno has put it. There is much more to the "meaning of the Middle Ages" at the dawn of the twenty-first century. We see and hear in the examples here considered a yearning for the Middle Ages, clear evidences of a postmodern approach to the past. In all three examples one can detect indeterminacies, fragmentation, the opening up of the musical canon, a lack of self, immanences as opposed to transcendance, performance, construction of worlds, hybrids, mixtures of "high" and "low," or "old" and "new." Interestingly enough, there is no irony present, no carnevalisation and no refraining from "meta narrative," to strain the meaning of this Lyotardian term to its limits. One could recognise a new form of virtual spirituality in the first example, the idea of the "time circle" serving as a "meta narrative" in the second, and virtual liturgy being the experiential product of the third. There is much empathy and respect for the medieval materials used in these examples, as in many late twentieth-century uses of medieval ideas and material including music.

Indeed, it is evident that the tremendous success of the Middle Ages in our time, of which the fascination with medieval music is only a small, if prominent, part, demonstrates a profound respect-sometimes even "amazement"-for the Middle Ages and a deep desire for its meaning, for meaning in general, for purpose, for renewed guidance and worth. What has fuelled this interest, aside from specific technical reasons for musicians dedicating themselves to the Middle Ages are three 
notions about the Middle Ages: that it serves as a reservoir for emotions and feelings; that it is the era of the witch and the wizard, the knight and the princess, a magic kingdom of secret knowledge and understanding of a sort lost in the Renaissance, Enlightenment, Industrial Revolution and twentieth century-a "kingdom" entered not through research or empirical knowledge, but through feeling; and that it is a time when humanity was in harmony with the universe, such that thoughts and feelings, the rational and the sensual, were dedicated to only one centre of supremacy. The Middle Ages was a time without time, an era in which the narration of its own historicity (unlike antiquity or the Renaissance) ceased.

Since we must "collaborate with the dead" (Page vii) in order to confront and revive the past, and since the dead are dead, we must speak for the past, and this certainly means taking it in, digesting it, and then re-creating it in ever new forms (Taylor). This means to a certain degree creating the past in front of our very eyes and ears, inhabiting castle and cathedral, so to speak, and trying hard "to regard what is strange in a text in such a way that the strangeness is retained and not sucked up by the categories of the modern observer" (Treitler, Tomlinson). We therefore might wish to describe the current revival of medieval music, itself a substantial part of the general interest in the Middle Ages, as depending upon the construction of the Middle Ages as a desired beyond or Other. While cultures developed extensive concepts of a world beyond or Jenseits in order to shape their present-a world beyond reflecting in many ways their own concept of themselves, their own systems of punishment, or reward, or hierarchical values-the "modern" human is sufficiently "enlightened" to shape a present with nothing but the present itself-or, then again, perhaps not. Again, a desired beyond has come to the fore, a "virtual" Beyond, creating in ourselves the vivid image of a lost world, which in turn has begun to shape our present. In the realm of music it is often even a semi-religious Beyond, one that requires neither participation nor sacrifice, neither radical commitment nor a definitive decision. Using medieval music for modern purposes simply gives the illusion of encountering the Other, celebrating virtual liturgies and introducing us to the mental experiment of history. Within the discontinuity, relativism and change spoken of by the various theorists of postmodernism, the continuing fascination with music and with the Middle Ages remains, going beyond emotion, and beyond feeling to the deepest layers of human existence. We look into the "distant mirror" of the Middle Ages, where we will imagine ourselves as not only seeing and hearing our dead ancestors, but seeing and hearing ourselves. And if we realise this and take it as an opportunity for deepening our realisation of who we really are, the value of the yearning for the Mid- 
dle Ages will go beyond our fondest hopes. Postmodernism has opened up the possibility of understanding the one looking into the mirror as well as understanding the mirror itself. ${ }^{l}$

University of Hamburg

1 Some ideas in this essay were presented in lectures given at Smith College in 1995 and at Hamburg University in 1996. Ruth Solie, Margaret Sarkissian, Peter Bloom, Wolfgang Dömling, Heimo Reinitzer, Dorothea Redepenning, and Richard Sherr offered helpful suggestions on the occasion of these lectures. In addition, the continuing dialogue with Susan Fast has been an inspiration to me. Last, but not least, Susanne Fontaine and Klaus Gertken, who introduced me to the realm of popular music, are to be thanked for their help.

\section{Works cited:}

Adorno, Theodor W. "Ohne Leitbild. Anstelle einer Vorrede," in Gesammelte Schriften Kulturkritik und Gesellschaft (Frankfurt am Main: Suhrkamp Verlag, 1977).

Bergeron, Katherine, "Finding God at Tower Records: The Virtual Sacred," The New Republic 27 February 1995.

. "A Lifetime of Chants" in Disciplining music: Musicology and its Canons eds K. Bergeron and P.V. Bohlmann (Chicago: U of Chicago, 1995a), pp. 182-96.

Bobko, Jane, ed. The Life and Music of Hildegard of Bingen text by Barbara Newman, commentary by Matthew Fox (New York: Penguin, 1995).

Bourdieu, Pierre. Zur Soziologie der symbolischen Formen (Frankfurt am Main: Suhrkamp Taschenbuch Verlag, 1974).

Cassirer, Ernst. Philosophie der symbolischen Formen (Darmstadt: Wissenschaftliche Buchgesellschaft, 1923, 1964).

Ebersole, Lucinda and Richard Peabody, eds Mondo Barbie (New York: St Martin's, 1993).

Elste, Martin. "Die Popularisierung mittelalterlicher Musik durch Schallplatten," in Mittelalter-Rezeption. Ein Symposium (=Germanistische Symposien-Berichtsbände, 
Bd. 6), ed. Peter Wapnewski (Stuttgart, 1986), pp. 547-54.

Ferneyhough, Brian. "On Klaus Huber," in Klaus Huber. Catalogue of Works. ed. G.

Ricordi (Feldkirchen bei München: Musikverlag G. Ricordi \& Co., 1994).

Goodman, Nelson. Ways of Worldmaking (Indianapolis, 1978).

Hassan, Ihab. "The Culture of Postmodernism," in Modernism. Challenges and Perspectives eds. Monique Chefdor, Ricardo Quinones and Albert Wachtel (Urbana, 1986).

Jencks, Charles, "The Emergent Rules," in Postmodemism. A Reader ed. Thomas Docherty (New York: Harvester Wheatsheaf, 1993), pp. 281-97.

Kenyon, Nicholas, ed. Authenticity and Early Music. A Symposium (Oxford: Oxford UP, 1988, 1994).

Kuspit, Donald. "The Contradictory Character of Postmodernism," in Postmodernism: Philosophy and the Arts (=Continental Philosophy III), ed. Hugh J. Silverman (New York: Routledge, 1990), pp. 53-68.

Levin, John. "Recreating Early Music," Rhythm Music Magazine III.8 (1994), pp. 34-5, 52-3.

--.--.-. "Sax and Polyphony," Rhythm Music Magazine IV.2 (1995), pp. 19-21.

Lyotard, Jean-François. Das postmoderne Wissen (=La condition postmoderne) (Vienna: Edition Passagen, 1994).

Page, Christopher. Voices and Instruments of the Middle Ages. Instrumental Practice and Songs in France 1100-1300 (London, 1987).

Rand, Erica. Barbie's queer accessories (Durham: Duke UP, 1995).

Salomon, Eva Maria and Martin. "Zurück in die Zukunft-Vorwärts in die Vergangenheit. Was macht Hildegard von Bingen in der Disco?" Musik und Bildung 4 (1995), pp. 26-9.

Sloterdijk, Peter. Kopernikanische Mobilmachung und ptolemäische Abrüstung. Ästhetischer Versuch (=edition subrkamp 1375) (Frankfurt am Main: Suhrkamp Verlag, 1987). 
Taruskin, Richard. Text and Act. Essays on Music and Performance (New York: Oxford UP, 1995).

Taylor, Gary. Cultural Selection. Why some Achievernents Survive the Test of Time-And Others Don't (New York: Basic Books, 1996).

Tomlinson, Gary. "The Web of Culture: A Context for Musicology," NineteenthCentury Music 7 (1984), pp. 350-62.

-----. Musical Pasts and Postmodern Musicologies: A Reply to Lawrence Kramer," Current Musicology 53 (1993), pp. 18-40.

Traub, Andreas. "Eine Perotin-Bearbeitung Hindemiths," Hindemith-Jahrbuch XXIII (Mainz, 1994), pp. 30-60.

Treitler, Leo. "What kind of story is history?" Nineteenth-Century Music 7 (1984), pp. 363-73.

-.-.-.-. Postmodern Signs in Musical Studies" Joumal of Musicology. A Quarterly Review of Music History, Criticism, Analysis, and Performance Practice 13 (1995).

Umbach, Klaus. "Gregor läßt grüßen," Der Spiegel 50 (1994).

-.----.. "Sülze im Binger Loch," Der Spiegel 9 (1995).

\section{Discography}

Chant (Canto Gregoriano) Choir of Santo Domingo de Silos. Deutsche Grammophone, 1994.

Enigma. MCMXC a.D Virgin Records, 1990.

Ensemble für Frühe Musik. Augsburg. The Ancient Miracles. CD. Christophorus No. 77178.

Jan Gabarek. The Hilliard Ensemble. Officium (=ECM New Series 152578118 21525-2) Munich, 1994.

Hildegard von Bingen. Canticles of Ecstasy Sequentia. Ensemble für mittelalterliche Musik Köln. Edition Classica. CD. Deutsche Harmonia mundi No. 05472 773202. New York: BMG Music, 1994. 


\section{Celestial Harmonies (No. Aris 13127).}

Celestial Light Tapestry, Telarc/Inakustik (No. 907200).

- Diadema Ensemble Vox, Erdenklang Musikverlag Ulrich Rützel 1990.

-...-... 11000 Virgins Anonymus IV, HMU/Helikon (No. 907200).

-.--.-.. A feather on the breath of God Gothic Voices. Ltg. Christopher Page. Hyperion (No. 66039).

-.-.-... Feminea forma Maria. Marienlieder des Villarenser Kodex Ensemble Mediatrix. Ltg. Johannes Berchmans Göschl. CD Calig. CAL 50982.

-.-.--. Heavenly Revelations, Hymns, Sequences, Antiphons, Responds Oxford Camerata, dir. Jeremy Summerly, 1993. Naxos CD No. 8550998.

------. Lieder und Antiphonen Instrumentalkreis Helga Weber. CD Christophorus (No. CHE 0041-2) 1980. Wiederauflage, 1993.

---.--. O Jerusalem Sequentia. Ensemble für mittelalterliche Musik Köln. Deutsche Harmonia mundi/BMG (No. 77346).

------. Symphoniae. Geistliche Gesänge Sequentia, Ensemble für mittelalterliche Musik. Köln. Editio Classica. LP and CD Deutsche Harmonia mundi (No. 770292-2-RG) 1989.

-..-.-... Voice of the Blood Sequentia. Ensemble für mittelalterliche Musik. Köln. Editio Classica. CD Deutsche Harmonia mundi No. 05472 773462. New York: BMG Music, 1995.

Hildegard von Bingen Ein Singspiel von Jutta Richter und Peter Janssens. Peter Janssens Musikverlag. CD 1081. 1998.

Klaus Huber. Cantiones de Circula Gyrante Ensemble Les Jeunes Solistes. Leitung Rachid Safir. CD. Montaigne No. MO 782060, 1995.

Medieval Babes. Salva Nos Virgin Records, 1997.

Meredith Monk/Hildegard von Bingen. Monk and the Abbess Musica Sacra, Ltg. Richard Westenburg, Catalyst/BMG (CD 68329). 
Neo-Medieval Medieval Improvisations for a Postmodern Age. Hesperus (=Dorian DIS-80155). New York, 1977.

Vision. The music of Hildegard of Bingen. Emily Van Evera and Germaine Fritz. OSB. Arrangement: Richard Souther. CD Angel Records, 1994/95. 